\title{
PENINGKATAN KAPASITAS SEL PADA SISTEM SELULER GSM
}

\author{
Alfin Hikmaturokhman ${ }^{1}$, Hesti Susilawati ${ }^{2}$, Shinta Yunita Sari ${ }^{3}$ \\ Akademi Teknik Telekomunikasi Sandhy Putra Purwokerto \\ E-mail : shinta_ys@plasa.com
}

\begin{abstract}
Increasing cell capacity in GSM applied by several methods such as Fixed Channel Allocation (FCA), Channel Sharing, Channel Borrowing and Cell Splitting to solve the massive increasing of celluler users amount in whole world. It necessary to calculate the number of subscriber within each cell in certain busy hour based on available channel capacity in order to serve the traffic capacity in a cell. In this work, we present calculations to compare cell capacity without increasing cell capacity method and cell capacity using increasing capacity methods. As a programming tool we used Borland Delphi 7. In addition, this simulation software added with comprehensive explanations, Erlang B Table, and graphics to make it easier and more efficient in analyze.
\end{abstract}

Keywords: GSM, Channel, Borlan Delphi 7.

\section{Pendahuluan}

1.1 Perumusan Permasalahan

Berdasarkan uraian diatas, ada beberapa permasalahan yang perlu diperhatikan yaitu sebagai berikut berapa jumlah kapasitas pelanggan (users) yang dapat dilayani dalam satu sel, berapa jumlah kapasitas pelanggan (users) yang dihasilkan dari peningkatan kapasitas sel pada sistem seluler ?, menbandingkan jumlah kapasitas pelanggan (users) yang dihasilkan antara kapasitas yang lama dengan kapasitas pelanggan yang menggunakan teknik peningkatan kapasitas sel.

\subsection{Tujuan Penulisan}

Beberapa tujuan yang ingin dicapai dalam penulisan : mengetahui jumlah kapasitas pelanggan (users) yang dapat dilayani dalam satu sel, mengetahui jumlah kapasitas pelanggan (users) yang dihasilkan dari peningkatan kapasitas sel pada sistem seluler, dapat menbandingkan jumlah kapasitas pelanggan (users) yang dihasilkan antara kapasitas yang lama dengan kapasitas pelanggan yang menggunakan teknik peningkatan kapasitas sel.

\section{Dasar Teori}

\subsection{Peningkatan Kapasitas sel}

a. Fixed Channel Allocation (FCA) ${ }^{3)}$

Strategi ini adalah dengan membagi seluruh kanal yang disediakan (M) menjadi $\mathrm{N}$ set kanal dimana $\mathrm{N}$ adalah jumlah sel per cluster.

1). FCA menggunakan antena omnidireksional

Jumlah pelanggan (M) dapat dihitung dengan cara [3] :

$$
M=\frac{\text { Ax60menit } / h r}{T}
$$

dimana $\mathrm{A}(\mathrm{N}, \mathrm{B})$ merupakan trafik yang disediakan (berdasarkan tabel Erlang B).

2). FCA menggunakan antena sektorisasi

Jumlah N per sektor :

Jumlah sel yang disediakan Jumlah sektor

Jumlah pelanggan (M) per sektor dapat dihitung seperti persamaan (2.1).

\section{b. Channel Sharring}

Channel sharring bergantung pada kondisi trafik setempat, pengelompokan kanal frekuensi dapat dibagi diantara dua cell sites jika menggunakan antena omnidireksional atau dibagi diantara dua permukaan pada cell sites jika 
menggunakan antena direksional (berarah).

1). Channel Sharring pada Sel menggunakan Antena Omni

A adalah besar trafik yang dihasilkan [3]:

$A \cong \frac{1}{2}\left[A\left(N_{1}, B\right)+A\left(N_{2}, B\right)-A(\Delta N, B)\right]$

Dimana :

$\mathrm{N}_{1}=$ jumlah kanal/sel

$\mathrm{N}_{2}=$ jumlah kanal yang dapat digunakan bersama dengan sel lain

$\Delta \mathrm{N}=\mathrm{N}_{2}-\mathrm{N}_{1}$

Sehingga jumlah users (M) yang tersedia dalam sel dapat dihitung seperti pada persamaan (2.1).

\section{2)Channel Sharing pada Sel menggunakan}

Direksional.

Perhitungan :

Jumlah $\mathrm{N}$ per sektor $=$

TotalJumlahKanalYangDisediakan JumlahSektor

Jumlah pelanggan (M) per sektor dapat dihitung berdasarkan persamaan (2.3) dan (2.1).

c. Channel Borrowing

Channel Borrowing biasanya dilakukan pada sistem FCA. Saat trafik density (kepadatan trafik) tidak dapat lagi didistribusikan ke seluruh coverage area, beberapa area memerlukan lebih banyak kanal untuk menyediakan kebutuhan layanan. Jumlah total user berdasarkan pada jumlah user pada dua sel. Pertama dengan mendifinisikan notasi yang digunakan yaitu :

$\mathrm{N}_{1}$ = jumlah kanal yang dialokasikan di setiap sel

$\Delta \mathrm{N}=$ kanal yang dipinjamkan

Jumlah beban trafik total yang ditawarkan (offered load) pada dua sel [3]:

$A^{\prime}=A\left(N_{1}+\Delta N, B\right)+A\left(N_{1}-\Delta N, B\right)$

(dalam dua sel)
Sehingga jumlah users yang dihasilkan berdasarkan persamaan (2.1).

\subsection{Coverage Area ${ }^{5)}$}

Area cakupan merupakan suatu wilayah tertentu yang masih dapat menangkap daya pancar BS (Base Station) sehingga dapat melaksanakan suatu proses komunikasi.

\section{a). Model Propagasi Hata}

1). Daerah Urban

Merupakan daerah yang terdiri dari banyak bangunan tinggi, kota besar (Model Eropa) [5].

Rumus :

$L_{50}(d B)=69,55+26,16 \log f_{c}-13,82 \log h_{t e}-a\left(h_{r e}\right) \ldots$
$+\left(44,9-6,55 \log h_{t e}\right) \log d$

dimana:

$\mathrm{f}_{\mathrm{c}}=$ frekuensi sinyal pembawa $(\mathrm{MHz})$

$\mathrm{L}_{50}=$ path loss rata-rata $(\mathrm{dB})$ $\mathrm{h}_{\mathrm{te}}=$ tinggi antena pemancar (meter) $\mathrm{a}\left(\mathrm{h}_{\mathrm{re}}\right)=$ faktor koreksi untuk tinggi antena penerima $(\mathrm{dB})$

$\mathrm{d}=$ jarak penerima dengan pemancar $(\mathrm{km})$

Model propagasi Hata mempunyai beberapa batasan parameter yaitu :

$$
\begin{aligned}
& 150 \leq \mathrm{f}_{\mathrm{c}} \leq 1500 \mathrm{MHz} \\
& 30 \leq \mathrm{h}_{\mathrm{te}} \leq 200 \text { meter } \\
& 1 \leq \mathrm{h}_{\mathrm{re}} \leq 10 \text { meter } \\
& 1 \leq \mathrm{d} \leq 20 \mathrm{~km}
\end{aligned}
$$

Sedangkan untuk faktor koreksi a $\left(\mathrm{h}_{\mathrm{re}}\right)$ dapat ditentukan dengan menyesuaikan daerah cakupan :

Untuk kota yang memiliki ukuran kecil dan menengah [5]:

$a\left(h_{r e}\right)=\left(1,1 \log f_{c}-0,7\right) h_{r e}-\left(1,56 \log f_{c}-0,8\right) \mathrm{dB} \ldots \ldots .(2.7)$

Untuk kota besar, pada frekuensi $f_{c} \leq 300 \mathrm{MHz}$ [5] :

$a\left(h_{r e}\right)=8,29\left(\log 1,54 h_{r e}\right)^{2}-1,1 \mathrm{~dB}$.

Untuk kota besar,pada frekuensi $f_{c} \geq 300 \mathrm{MHz}$ [ [5] :

$a\left(h_{r e}\right)=3,2\left(\log 11,75 h_{r e}\right)^{2}-4,97 \mathrm{~dB} \ldots$

\section{2). Daerah Suburban}

Suatu daerah dikatakan daerah suburban (pinggiran) jika terdapat penghalang (obstacle) disekitar MS namun tidak terlalu rapat. Kerapatan penduduk untuk daerah suburban sekitar $500-7.500$ penduduk $/ \mathrm{km}^{2}$. 


\section{Rumus [5]:}

$L_{50}(d B)=L_{50}($ urban $)-2\left[\log \left(f_{c} / 28\right)\right]^{2}-5,4 \mathrm{~dB} \ldots$

\section{3). Daerah terbuka}

Suatu daerah dikatakan terbuka jika tidak ada penghalang (obstacle) pada jarak $300-400$ meter dari arah base station dan umumnya juga disekitar lokasi MS berada. Kerapatan penduduk untuk daerah urban sekitar 7.500 20.000 penduduk $/ \mathrm{km}^{2}$.

\section{Rumus [5]:}

$L_{50}(d B)=L_{50}($ urban $)-4,78\left[\log \left(f_{c}\right)\right]^{2}+18,33 \log f_{c}-40,98 \cdots \cdots$

\section{b. Model Propagasi COST-231}

$L_{\mathrm{s} 0}($ urban $)=46,3+33,9 \log f_{c}-13,82 \log h_{t e}-a\left(h_{r e}\right)$.

$+\left(44,9-6,55 \log h_{t e}\right) \log d+C_{m}$

$\mathrm{a}\left(\mathrm{h}_{\mathrm{re}}\right)$ tetap didefinisikan sesuai dengan persamaan (2.7), (2.8), (2.9) sementara $C_{m}$ bernilai:

$\mathrm{Cm}=0 \mathrm{~dB}$ untuk wilayah pinggiran dan kota berukuran sedang

$\mathrm{Cm}=3 \mathrm{~dB}$ untuk kota metropolitan.

Pengembangan Model Hata dalam COST-231 dibatasi dengan parameterparameter sebagai berikut :

$\mathrm{f}_{\mathrm{c}}=1500 \mathrm{MHz}$ sampai $2000 \mathrm{MHz}$

$\mathrm{h}_{\mathrm{te}}=30$ meter sampai 200 meter

$\mathrm{h}_{\mathrm{re}}=1$ meter sampai 10 meter

$\mathrm{d}=1 \mathrm{Km}$ sampai $20 \mathrm{Km}$

\subsection{Luas Sel}

Setelah nilai radius sel maksimum diketahui dengan menggunakan perhitungan model propagasi Hata dan atau dengan model propagasi COST-231, dapat dicari nilai luas maksimum sel heksagonal dengan persamaan [2]:

$$
L_{s e l}=2,6 \cdot R^{2} \quad\left(\mathrm{~km}^{2}\right)
$$

dimana :

$\mathrm{L}_{\mathrm{se}}=$ luas sel heksagonal $\left(\mathrm{km}^{2}\right)$

$\mathrm{R}=\operatorname{radius} \operatorname{sel}(\mathrm{km})$

Luas sel tentunya adalah luas daerah pelayanan dibagi dengan jumlah sel yang terhitung dari bagian sebelumnya [2] :

$$
L_{\text {sel }}=\frac{\text { LuasDaerah }}{\sum \text { sel }}
$$

\subsection{Teknik Cell Splitting}

Pada saat kepadatan trafik mulai terlihat serta frekuensi di dalam setiap sel sudah tidak mampu lagi menampung jumlah panggilan (call) pelanggan bergerak, maka sel yang asli dapat di split (dibelah) menjadi sel-sel yang lebih kecil. Biasanya radius liputan yang baru adalah sama dengan setengah dari radius liputan sel asli. Perhatikan gambar 2.15 berikut :

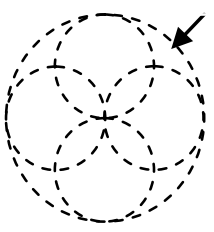

(a)

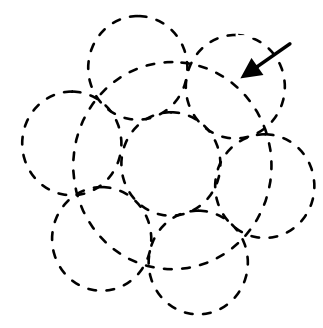

(b)
Gambar 2.15 Cell splitting ${ }^{7)}$

Untuk melakukan cell splitting ada dua jalan. Pada gambar (a) menunjukkan bahwa sel asli tidak digunakan lagi sedangkan gambar (b) menunjukkan bahwa [7] :

$$
\text { RadiusSelBaru }=\frac{\text { RadiusSelLama }}{2}
$$

Dari persamaan tersebut dapat dibuat persamaan [7]:

$$
\text { AreaSelBaru }=\frac{\text { AreaSelLama }}{4}
$$

Selanjutnya setiap sel yang baru akan memuat beban trafik maksimum yang sama dengan beban trafik lama. Secara teori dapat ditulis beban trafik yang baru sama dengan 4 kali beban trafik yang lama.

\section{Analisa dan Pembahasan}

3.1 Perbandingan Kapasitas Jumlah Users antara FCA Omnidireksional dengan Channel Sharing Omnidireksional

1). Perhitungan FCA Omnidireksional

a. Jumlah kanal per sel yang disediakan $(\mathrm{N})=60$ kanal

b. Dengan waktu pendudukan $(\mathrm{T})=1,76$ menit

a) Dengan menggunakan probabilitas blocking $2 \%$

Menghasilkan jumlah pelanggan (M) sebanyak :

$$
\begin{gathered}
M=\frac{\text { Ax60menit } / \mathrm{hr}}{T} \\
=1690 \mathrm{user}
\end{gathered}
$$


b) Dengan menggunakan probabilitas blocking 5\%

Menghasilkan jumlah pelanggan sebanyak:

$M=\frac{\text { Ax60menit } / \mathrm{hr}}{T}$

$=1861 \quad$ user

\section{2) Perhitungan Channel Sharing} Omnidireksional

a. Jumlah kanal per sel yang disediakan $\left(\mathrm{N}_{1}\right)=60 \mathrm{kanal}$

b. Jumlah kanal dari setiap sel yang dapat saling dipergunakan $(\Delta \mathrm{N})=15$ kanal

c. $\mathrm{N}_{2}=\mathrm{N}_{1}+\Delta \mathrm{N}=60+15=75 \mathrm{kanal}$

d. Dengan waktu pendudukan $(\mathrm{T})=1,76$ menit

a). Dengan menggunakan probabilitas blocking $2 \%$

A dihasilkan berdasarkan persamaan (2.3) :

$$
A \cong \frac{1}{2}\left[A\left(N_{1} ; B\right)+A\left(N_{2} ; B\right)-A(\Delta N ; B)\right]
$$

$=52,245$ Erlang

Sehingga menghasilkan jumlah pelanggan $(\mathrm{M})$ :

$$
\begin{aligned}
M & =\frac{\text { Ax60menit } / \mathrm{hr}}{T} \\
& =1781 \mathrm{user}
\end{aligned}
$$

\section{b). Dengan menggunakan}

\section{probabilitas blocking $5 \%$}

A dihasilkan berdasarkan persamaan (2.3):

$$
\begin{aligned}
A & \cong \frac{1}{2}\left[A\left(N_{1} ; B\right)+A\left(N_{2} ; B\right)-A(\Delta N ; B)\right] \\
& =56,85 \quad \text { Erlang }
\end{aligned}
$$

Menghasilkan jumlah pelanggan (M) sebanyak :

$$
\begin{aligned}
M & =\frac{\text { Ax60menit } / \mathrm{hr}}{T} \\
& =1938 \text { user }
\end{aligned}
$$

Grafik yang dihasilkan antara FCA Omnidireksional dengan Channel Sharing Omnidireksional dengan Probabilitas Blocking 2\%

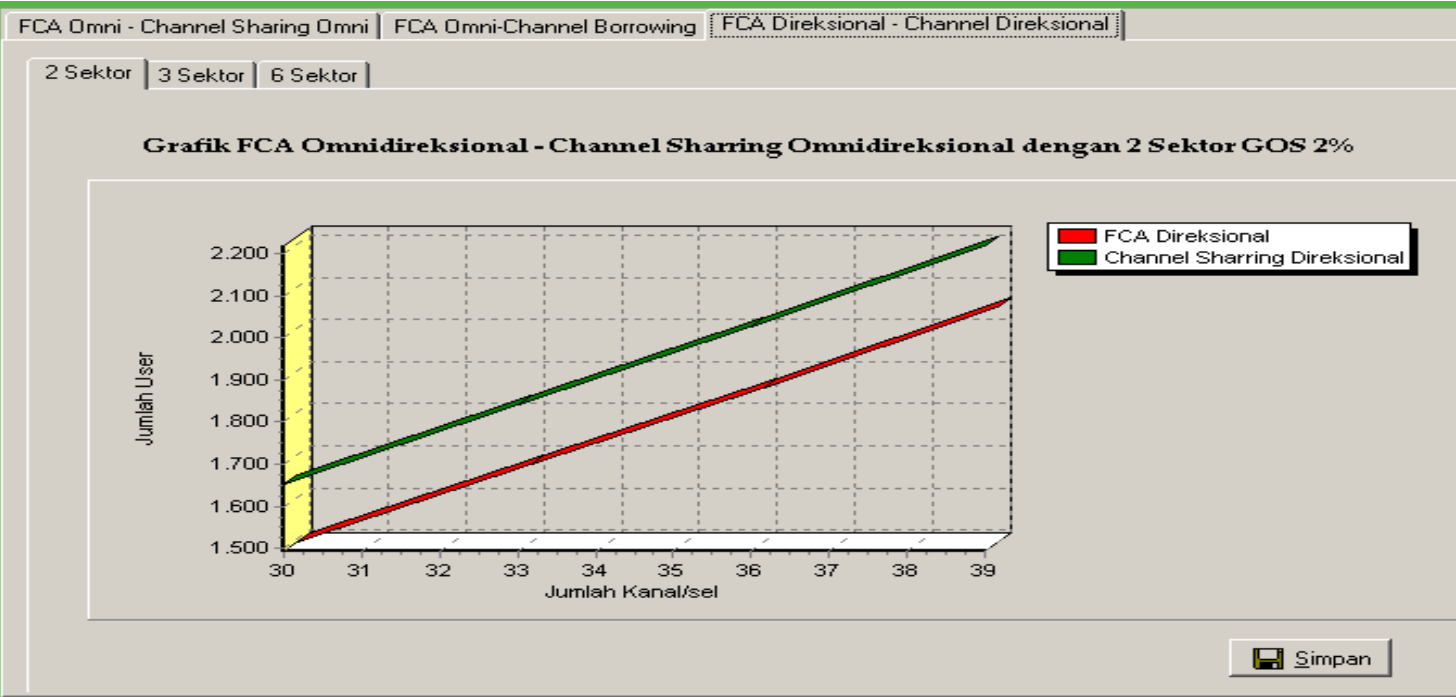

Gambar 4.5 Grafik perbandingan antara FCA Omnidireksional dengan Channel Sharing Omnidireksional dengan Probabilitas Blocking $2 \%$ 
Dari gambar 4.5 yang dihasilkan dari perhitungan FCA Omnidireksional dengan Channel Sharing omnidireksional dengan probabilitas blocking yang digunakan sebesar 2\%, terlihat peningkatan kapasitas pelanggan terjadi dengan menggunakan teknik channel sharing, diasumsikan dengan kanal yang tersedi sebanyak 60 kanal dapat melayani
1690 pelanggan sedangkan pada channel sharring dapat melayani 1781 pelanggan sehinnga terdapat selisih sebanyak 91 kanal lebih banyak dengan menggunakan channel sharing, semakin banyak kanal yang tersedia maka akan semakin banyak pelanggan yang dapat dilayani.

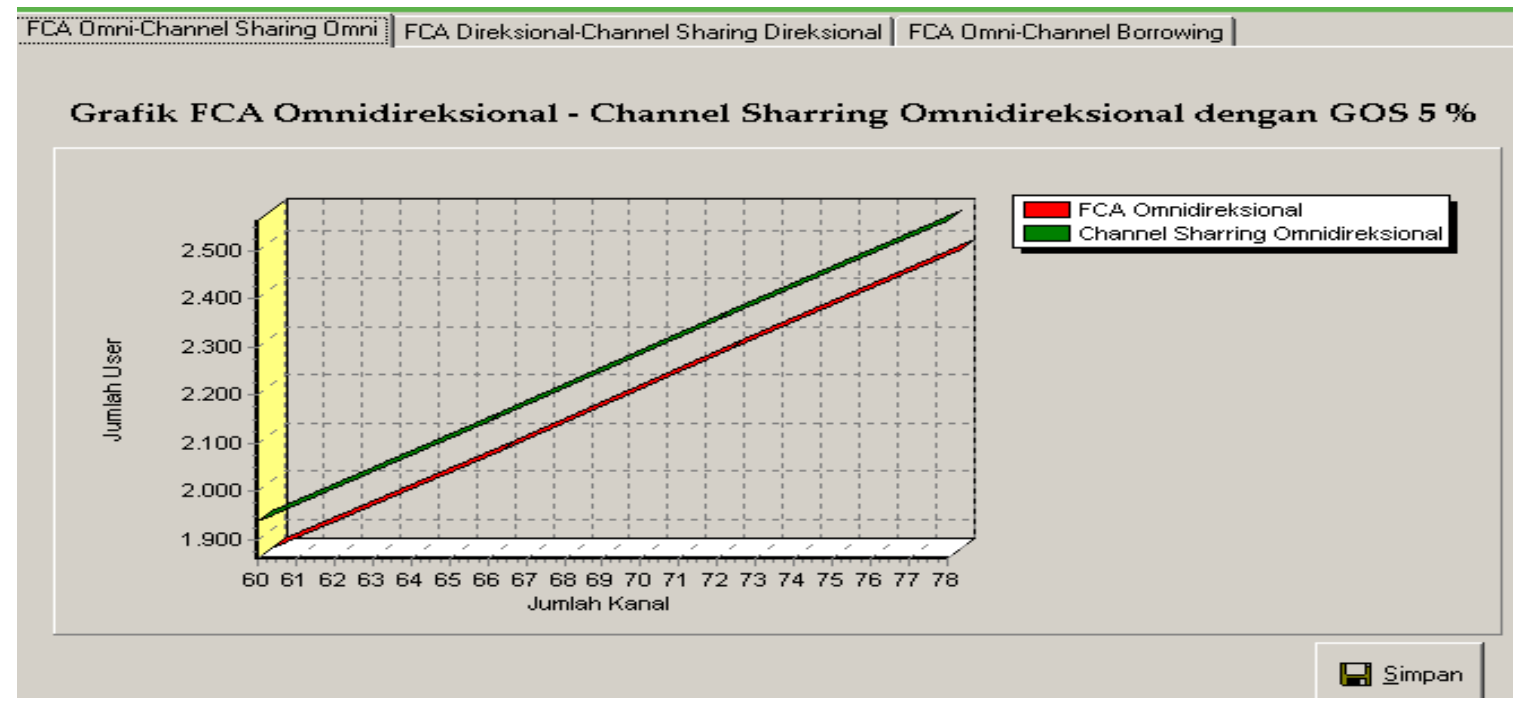

Gambar 4.6 Grafik perbandingan antara FCA Omnidireksional dengan Channel Sharing Omnidireksional dengan Probabilitas Blocking $5 \%$

Sama halnya dengan penjelasan sebelumnya pada gambar 4.6 terjadi peningkatan kapasitas pelanggan dengan cara membandingkan antara sistem FCA dengan channel sharing omdireksional hanya perbedaannya terdapat pada penggunaan probabilitas blocking yang digunakan yaitu 5\%. Bila ditinjau dari segi kapasitas pelanggan berdasarkan probabilitas yang digunakan, probabilitas 5\% lebih banyak menghasilkan jumlah pelanggan lebih banyak dibandingkan dengan menggunakan probabilitas $2 \%$, namun semakin tinggi tingkat probabilitas blocking yang digunakan semakin banyak pula peluang pemblokingan suatu panggilan.

\subsection{Perbandingan Kapasitas Jumlah Users antara FCA Direksional dengan Channel Sharing Direksional \\ 1) FCA Direksional dengan Channel Sharing Direksional dengan 2 sektor dan menggunakan probabilitas $2 \%$.}

a. Jumlah kanal per sel yang disediakan $(\mathrm{N})=60$ kanal

b. Sehingga diperoleh jumlah kanal/ sel dengan menggunakan persamaan (2.2) :

disediakan

$$
\begin{aligned}
& \text { Jumlah N per sekt }= \\
& \text { Jumlah sel yang }
\end{aligned}
$$

Jumlah sektor

$$
=30 \mathrm{kanal} / \mathrm{sel}
$$

c. Jumlah kanal dari setiap sel yang dapat saling dipergunakan $(\Delta \mathrm{N})=15$ kanal

d. $\mathrm{N}_{2}=\mathrm{N}_{1}+\Delta \mathrm{N}=30+15=45$ kanal

e. Dengan waktu pendudukan (T) $=1,76$ menit

\section{a). Perhitungan FCA}

Menghasilkan jumlah pelanggan (M) berdasarkan persamaan (2.1) sebanyak:

$$
M=\frac{\text { Ax60menit } / \mathrm{hr}}{T}
$$


$=746,59$ user/sektor

Dengan 2 sektor, kapasitas pelanggan yang dihasilkan dalam sebuah sel dapat dihitung berdasarkan persamaan (2.1):

$M=\frac{A x 60 \text { menit } / h r}{T} \mathrm{xJumlahSektor}($ users/cel $)$

$$
=1493 \text { user }
$$

\section{2). Perhitungan Channel Sharing}

A adalah besar trafik yang dihasilkan berdasarkan persamaan (2.3):

$A \cong \frac{1}{2}\left[A\left(N_{1} ; B\right)+A\left(N_{2} ; B\right)-A(\Delta N ; B)\right]$
$=24,245 \quad$ Erlang

Jumlah pelanggan (M) berdasarkan persamaan (2.1) sebanyak :

$$
\begin{aligned}
M & =\frac{\text { Ax60menit } / \mathrm{hr}}{T} \\
& =826,534 \mathrm{user} / \text { sektor }
\end{aligned}
$$

Dengan 2 sektor sehingga kapasitas pelanggan yang dihasilkan dalam sebuah sel dapat dihitung berdasarkan persamaan (2.1) : $M=\frac{\text { Ax60menit } / h r}{T}$ XJumlahsektor(users/ce l)

$$
=1653 \text { user }
$$

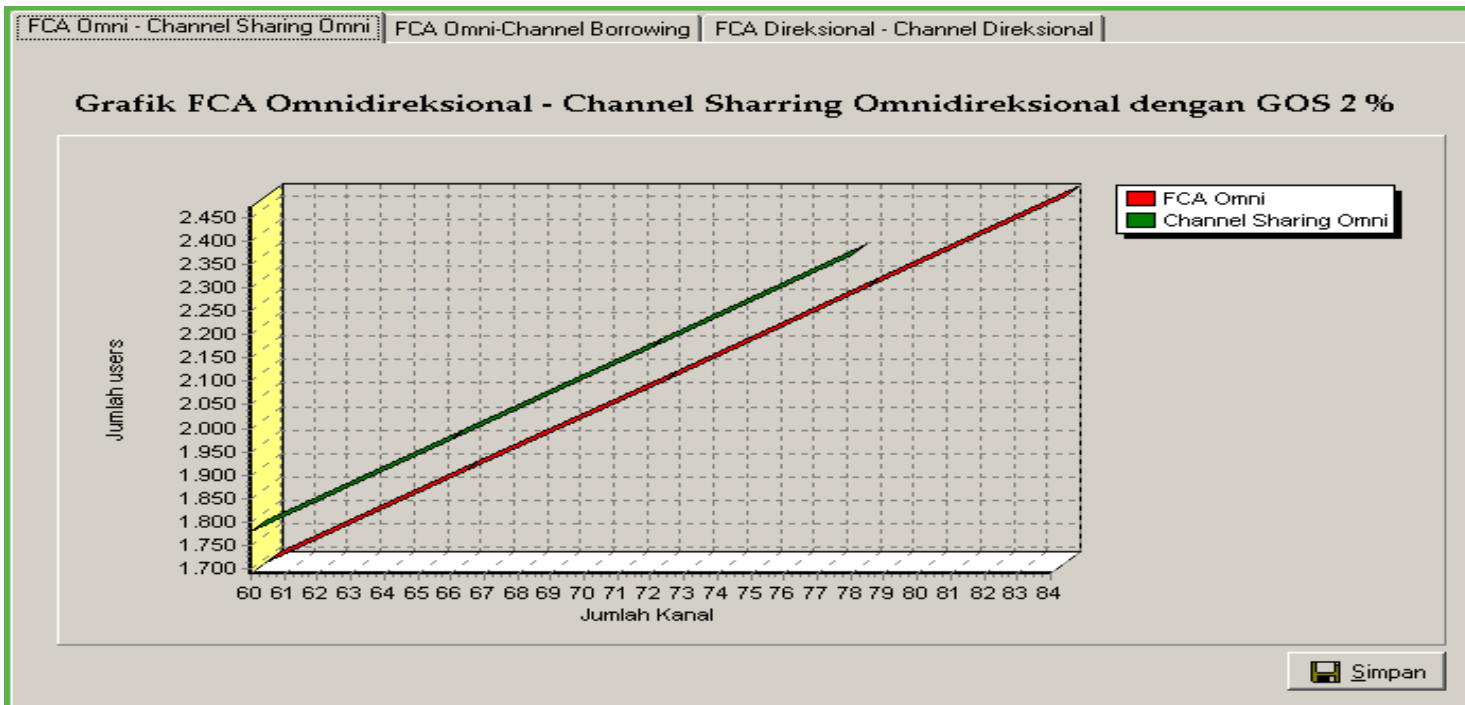

Gambar 4.9 Grafik Perbandingan FCA Direksional dengan Channel Sharring 2 sektor menggunakan probabilitas blocking $2 \%$

Pada gambar 4.9 diatas menunjukkan perbandingan peningkatan kapasitas sel antara FCA direksional dengan channel sharring direksional 2 sektor, 2 sektor disini dimaksudkan perarahan antena yang digunakan dibagi ke dalam 2 sektor yang masing-masing sektornya memiliki kapasitas kanal tertentu. Dimana untuk kapasitas keseluruhan kanal yang disediakan dalam satu sel dikalikan sebanyak jumlah sektor yang digunakan, begitu pula pada sektor yang lainya yaitu 3 sektor dan 6 sektor. Dari gambar 4.9 menampilkan grafik perbandingan peningkatan kapasitas dimana walaupun sebuah sel memiliki antena yang berarah (direksional) dengan menggunakan teknik channel sharring direksional tetap dapat mengalami peningkatan kapasitas.

2) FCA Direksional dengan Channel Sharing dengan 3 sektor dan menggunakan probabilitas $2 \%$.

a.Jumlah kanal per sel yang disediakan (N) $=60 \mathrm{kanal}$

b. Sehingga diperoleh jumlah kanal/ sel dengan menggunakan persamaan (2.2) : Jumlah Npersektor $=$

disediakan Jumlah sel yang

$$
\begin{aligned}
& \text { Jumlah sektor } \\
& =20 \quad \mathrm{kanal} / \mathrm{sel}
\end{aligned}
$$

c. Jumlah kanal dari setiap sel yang dapat saling dipergunakan $(\Delta \mathrm{N})=15 \mathrm{kanal}$ d. $\mathrm{N}_{2}=\mathrm{N}_{1}+\Delta \mathrm{N}=20+15=35 \mathrm{kanal}$ 
e. Dengan waktu pendudukan $(\mathrm{T})=1,76$ menit

\section{a). Perhitungan FCA}

Jumlah pelanggan (M) berdasarkan persamaan (2.1) sebanyak :

$$
\begin{aligned}
& M=\frac{\text { Ax60menit } / \mathrm{hr}}{T} \\
& =450 \text { user/sektor }
\end{aligned}
$$

Dengan 3 sektor sehingga kapasitas pelanggan yang dihasilkan dalam sebuah sel dapat dihitung berdasarkan persamaan (2.1)

$M=\frac{\text { Ax60menit } / \mathrm{hr}}{T} \mathrm{xJumlahsektor}($ users/cel)

$$
=1350 \text { user }
$$

\section{b). Perhitungan Channel Sharring}

A adalah besar trafik yang dihasilkan bersadarkan persamaan (2.3):

$$
\begin{gathered}
A \cong \frac{1}{2}\left[A\left(N_{1} ; B\right)+A\left(N_{2} ; B\right)-A(\Delta N ; B)\right] \\
=15,295 \quad \text { Erlang }
\end{gathered}
$$

Menghasilkan jumlah pelanggan (M) berdasarkan persamaan sebanyak:

$$
\begin{aligned}
M & =\frac{\text { Ax60menit } / \mathrm{hr}}{T} \\
& =521,42 \text { user/sektor }
\end{aligned}
$$

Dengan 3 sektor sehingga kapasitas pelanggan yang dihasilkan dalam sebuah sel dapat dihitung berdasarkan persamaan (2.2) :

$$
\begin{aligned}
& M=\frac{\text { Ax60menit } / \mathrm{hr}}{T} \mathrm{XJumlahsektor} \\
& \text { (users/cel) } \\
& \quad=1564 \mathrm{user}
\end{aligned}
$$

Berdasarkan hasil perhitungan Channel Sharring Direksional dengan 3 sektor dan menggunakan probablitas $2 \%$, menghasilkan grafik 4.12. Tampak pada gambar 4.12, skema FCA dan channel sharring dengan menggunakan 3 sektor dengan kanal yang tersedia sebanyak $60 \mathrm{kanal} / \mathrm{sel}$, pada channel sharring mengalami peningkatan jumlah pelanggan dengan sistem pembagian kanal, semakin besar kanal yang disediakan maka semakin menigkat kapasitas yang disediakan.

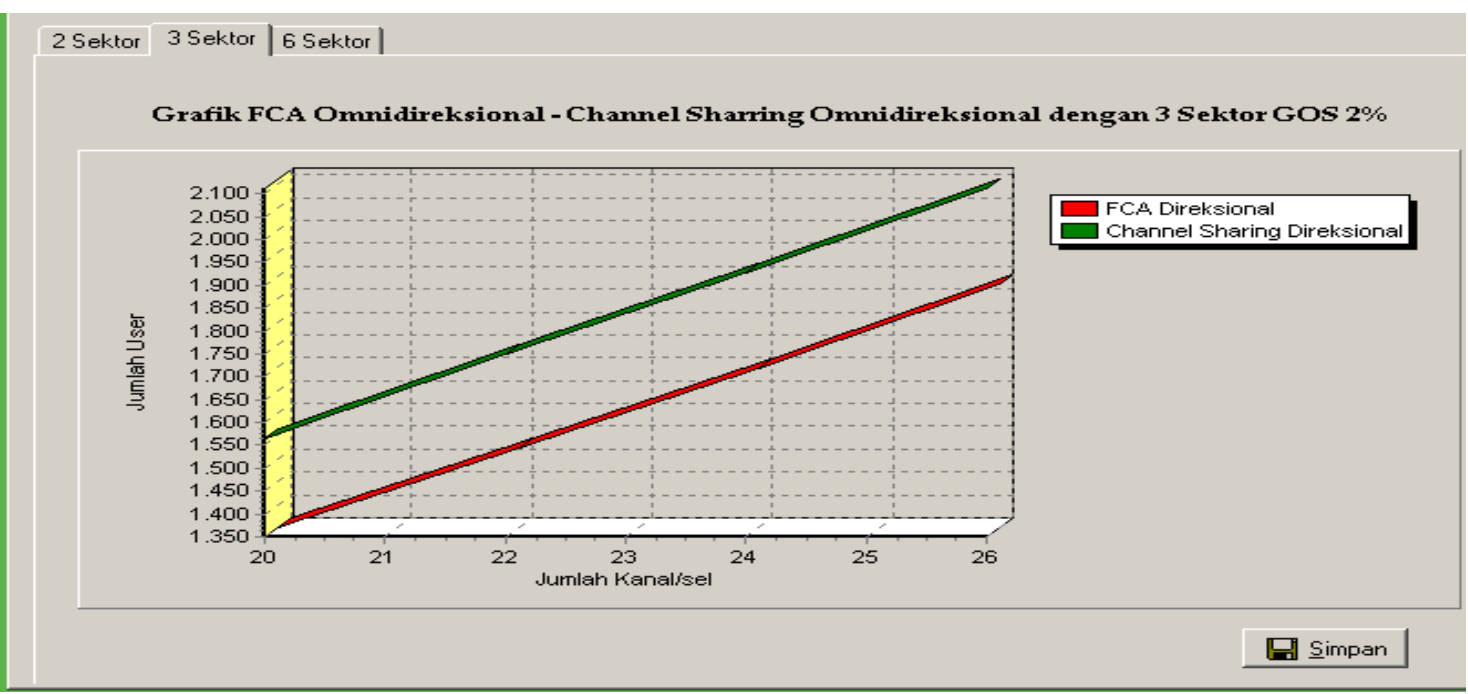

Gambar 4.12 Grafik Perbandingan FCA Direksional dengan Channel Sharring 3 sektor menggunakan probabilitas blocking $2 \%$

\section{3) FCA Direksional dengan Channel \\ Sharing dengan 6 sektor dan menggunakan probabilitas $2 \%$.}

a. Jumlah kanal per sel yang disediakan(N) $=60 \mathrm{kanal}$ b. Sehingga diperoleh jumlah kanal/ sel dengan menggunakan persamaan (2.2) :

Jumlah Nper sektor=
Jumlah sel yang
disediakan

Jumlah sektor 
$=10 \mathrm{kanal} / \mathrm{sel}$

c. Jumlah kanal dari setiap sel yang dapat saling dipergunakan $(\Delta \mathrm{N})=15 \mathrm{kanal}$

d. $\mathrm{N}_{2}=\mathrm{N}_{1}+\Delta \mathrm{N}=10+15=25 \mathrm{kanal}$

e. Dengan waktu pendudukan $(\mathrm{T})=1,76$ menit

\section{a). Perhitungan FCA}

Jumlah pelanggan

berdasarkan persamaan

sebanyak :

$$
\begin{gathered}
M=\frac{\text { Ax60menit } / \mathrm{hr}}{T} \\
=173,18 \text { user/sektor }
\end{gathered}
$$

Dengan 6 sektor, kapasitas pelanggan yang dihasilkan dalam sebuah sel dapat dihitung berdasarkan persamaan (2.19) :

$$
\begin{aligned}
& M=\frac{\text { Ax60menit } / \mathrm{hr} r}{T} \text { xJumlahsektor } \\
& \begin{array}{l}
\text { (users/cel) } \\
\quad=1039 \text { user }
\end{array}
\end{aligned}
$$

\section{2). Perhitungan Channel Sharing}

A adalah besar trafik yang dihasilkan berdasarkan persamaan (2.3):
Jumlah pelanggan (M) sebanyak:

$$
\begin{aligned}
M & =\frac{\text { Ax60menit } / \mathrm{hr}}{T} \\
& =231,307 \text { user/sektor }
\end{aligned}
$$

Dengan 6 sektor sehingga kapasitas pelanggan yang dihasilkan dalam sebuah sel dapat dihitung berdasarkan persamaan (2.2) :

$$
\begin{gathered}
M=\frac{\text { Ax60menit } / \mathrm{hr}}{T} \text { XJumlahsektor } \\
\text { (users/cel) }=1387 \text { user }
\end{gathered}
$$

Gambar 4.15 merupakan grafik hasil perbandingan antara FCA direksional dan channel sharing 6 sektor dengan B sebesar $2 \%$, pada sel yang terbagi menjadi 6 sektor juga dapat mengalami peningkatan kapasitas pelanggan, dengan kapasitas yang tersedia untuk setiap sektor dikalikan sebanyak sektor yang digunakan, tampak bahwa terjadi peningkatan dibandingkan dengan kapasitas yag disediakan pada awalnya.

$$
\begin{aligned}
A \cong & \frac{1}{2}\left[A\left(N_{1} ; B\right)+A\left(N_{2} ; B\right)-A(\Delta N ; B)\right] \\
& =6,785 \quad \text { Erlang }
\end{aligned}
$$

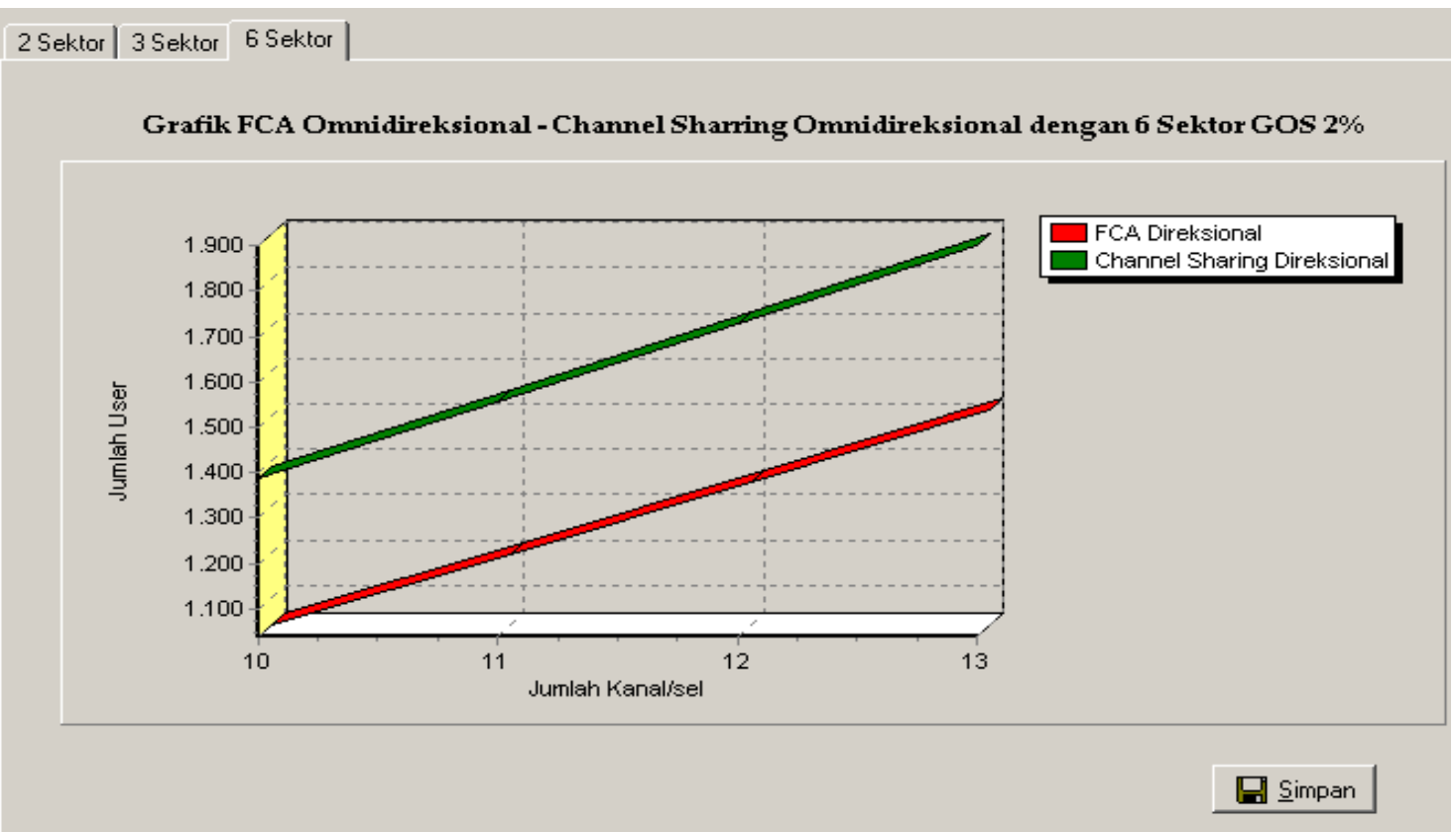

Gambar 4.15 Grafik Perbandingan FCA Direksional dengan Channel Sharring 6 sektor menggunakan probabilitas blocking $2 \%$ 
1) FCA Direksional dengan Channel Sharring dengan 2 sektor dan menggunakan probabilitas $5 \%$.

a. Jumlah kanal per sel yang disediakan (N) $=60 \mathrm{kanal}$

b. Sehingga diperoleh jumlah kanal/ sel dengan menggunakan persamaan (2.2) :

Jumlah Nper sektor= Jumlah sel

yangdisediakan

Jumlah sektor

$$
\begin{aligned}
= & \frac{60}{2} \\
= & 30 \quad \mathrm{kanal} / \mathrm{sel}
\end{aligned}
$$

c. Jumlah kanal dari setiap sel yang dapat saling dipergunakan $(\Delta \mathrm{N})=15 \mathrm{kanal}$

d. $\mathrm{N}_{2}=\mathrm{N}_{1}+\Delta \mathrm{N}=30+15=45 \mathrm{kanal}$

e. Dengan waktu pendudukan $(\mathrm{T})=1,76$ menit

a). Perhitungan FCA

Jumlah pelanggan (M) berdasarkan persamaan (2.1) sebanyak :

$$
M=\frac{\text { Ax60menit } / \mathrm{hr}}{T}
$$

$=845,45$ user $/$ sektor

Menggunakan 2 sektor sehingga kapasitas pelanggan yang dihasilkan dalam sebuah sel dapat dihitung berdasarkan persamaan

$$
M=\frac{\text { Ax60menit } / \mathrm{hr}}{T} \mathrm{x}
$$

Jumlah sektor (users/cel)

$$
=1690 \text { user }
$$

\section{2). Perhitungan Channel Sharing}

A adalah besar trafik yang dihasilkan berdasarkan persamaan (2.4):

$$
\begin{aligned}
A \cong & \frac{1}{2}\left[A\left(N_{1} ; B\right)+A\left(N_{2} ; B\right)-A(\Delta N ; B)\right] \\
& =26,9 \quad \text { Erlang }
\end{aligned}
$$

Sehingga menghasilkan jumlah pelanggan (M) berdasarkan persamaan (2.1) sebanyak

$$
\begin{aligned}
M & =\frac{\text { Ax60menit } / \mathrm{hr}}{T} \\
& =917,045 \text { user/sektor }
\end{aligned}
$$

Menggunakan 2 sektor sehingga kapasitas pelanggan yang dihasilkan dalam sebuah sel dapat dihitung berdasarkan persamaan (2.3) :

$M=\frac{\text { Ax60menit } / h r}{T}$ xJumlah $\quad$ sektor (users/cel)

$$
=1834 \text { user }
$$

Perbandingan adanya peningkatan kapasitas pelanggan ditunjukkan pada gambar 4.17 dengan menggunakan channel sharing 2 sektor untuk Gos $5 \%$, mengalami peningkatan dibandingkan dengan skema FCA dengan waktu pendudukan yang sama dengan kapasitas pelanggan sebesar 1690 user menjadi 1834 user yang disediakan.

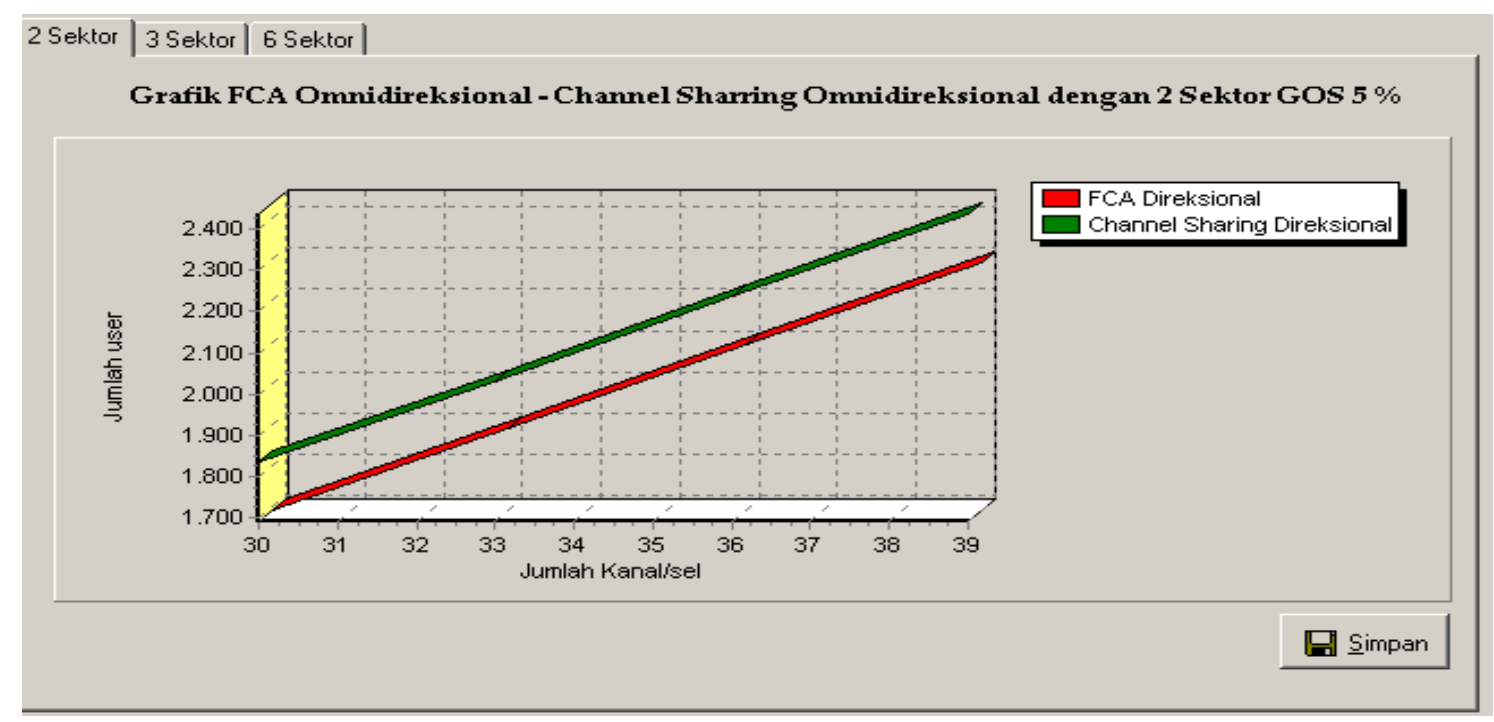

Gambar 4.18 Grafik Perbandingan FCA Direksional dengan Channel Sharring 2 sektor menggunakan probabilitas blocking 5\% 
2) FCA Direksional dengan Channel Sharing dengan 3 sektor dan menggunakan probablitas $5 \%$.

a. Jumlah kanal per sel yang disediakan (N) $=60 \mathrm{kanal}$

b. Sehingga diperoleh jumlah kanal/ sel dengan menggunakan persamaan (2.1) :

Jumlah Nper sektor= Jumlah sel

yangdisediakan

$$
\begin{aligned}
& =\frac{60}{3} \\
& =20 \mathrm{kanal} / \mathrm{sel}
\end{aligned}
$$$$
\text { Jumlah sektor }
$$

c. Jumlah kanal dari setiap sel yang dapat saling dipergunakan $(\Delta \mathrm{N})=15$ kanal

d. $\mathrm{N}_{2}=\mathrm{N}_{1}+\Delta \mathrm{N}=20+15=35 \mathrm{kanal}$

e. Dengan waktu pendudukan $(\mathrm{T})=1,76$ menit

\section{a). Perhitungan FCA}

Menghasilkan jumlah pelanggan (M) berdasarkan persamaan (2.1) sebanyak :

$$
\begin{aligned}
M & =\frac{\text { Ax60menit } / \mathrm{hr}}{T} \\
& =518,18 \mathrm{user} / \mathrm{sektor}
\end{aligned}
$$

Untuk 3 sektor kapasitas pelanggan yang dihasilkan dalam sebuah sel dapat dihitung berdasarkan persamaan (2.3):

$M=\frac{A x 60 m e n i t / h r}{T} \times$ Jumlah sektor

$$
=1554,54 \text { user }
$$

\section{b). Perhitungan Channel Sharing}

A adalah besar trafik yang dihasilkan berdasarkan persamaan (2.4):

$$
\begin{aligned}
A \cong & \frac{1}{2}\left[A\left(N_{1} ; B\right)+A\left(N_{2} ; B\right)-A(\Delta N ; B)\right] \\
& =17,15 \quad \text { Erlang }
\end{aligned}
$$

Sehingga menghasilkan jumlah pelanggan (M) berdasarkan persamaan (2.1) sebanyak

$$
\begin{aligned}
M & =\frac{\text { Ax60menit } / \mathrm{hr}}{T} \\
& =584,66 \text { user/sektor }
\end{aligned}
$$

Dengan menggunkan 3 sektor kapasitas pelanggan yang dihasilkan dalam sebuah sel dapat dihitung berdasarkan persamaan (2.3) : $M=\frac{\text { Ax60menit } / h r}{T} \times$ Jumlah sektor $=1753$ user

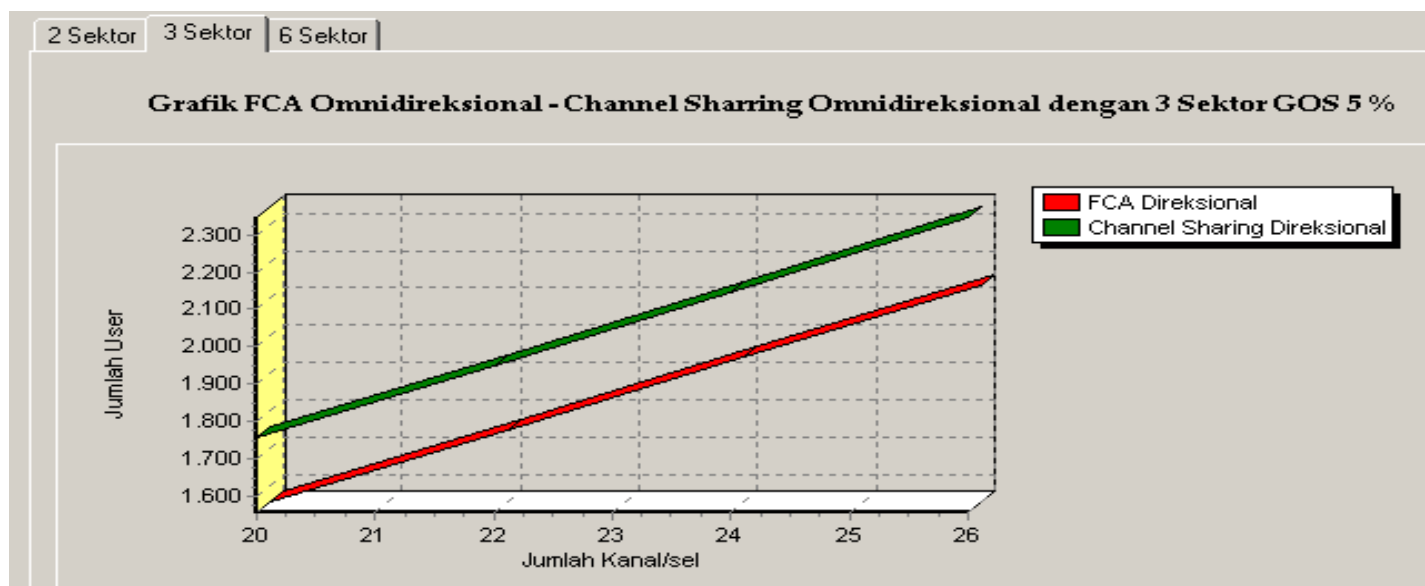

묘 Simpan

Gambar 4.21 Grafik Perbandingan FCA Direksional dengan Channel Sharring 3 sektor menggunakan probabilitas blocking $5 \%$

Gambar 4.21 telah membuktikan adanya peningkatan kapasitas dengan menggunakan channel sharring 3 sektor, dengan nilai yang berbanding lurus anatara jumlah kanal yang tersedia dengan jumlah pelanggan yang dapat dilayani dalam sebuah sel.

3) FCA Direksional dengan Channel Sharing dengan 6 sektor dan menggunakan probabilitas $5 \%$. 
a. Jumlah kanal per sel yang disediakan $(\mathrm{N})$ $=60 \mathrm{kanal}$

b. Sehingga diperoleh jumlah kanal/ sel dengan menggunakan persamaan (2.3) :

Jumlah Nper sektor=

disediakan

$$
\text { Jumlah sel yang }
$$

Jumlah sektor

$$
=10 \mathrm{kanal} / \mathrm{sel}
$$

c. Jumlah kanal dari setiap sel yang dapat saling dipergunakan $(\Delta N)=15$ kanal

d. $\mathrm{N}_{2}=\mathrm{N}_{1}+\Delta \mathrm{N}=10+15=25$ kanal

e. Dengan waktu pendudukan $(\mathrm{T})=1,76$ menit

\section{a). Perhitungan FCA}

Menghasilkan jumlah pelanggan (M) berdasarkan persamaan (2.1) sebanyak : $M=\frac{\text { Ax60menit } / \mathrm{hr}}{T}$

\section{$=212,045$ user/sektor}

Pada FCA 6 sektor menghasilkan kapasitas pelanggan dalam sebuah sel dapat dihitung berdasarkan persamaan (2.3) :

$M=\frac{\text { Ax60menit } / h r}{T} \times$ Jumlah sektor

$$
=1272 \text { user }
$$

\section{b) Perhitungan Channel Sharing}

A adalah besar trafik yang dihasilkan bersadarkan persamaan (2.4):

$$
\begin{gathered}
A \cong \frac{1}{2}\left[A\left(N_{1}, B\right)+A\left(N_{2}, B\right)-A(\Delta N, B)\right] \\
=7,81 \quad \text { Erlang }
\end{gathered}
$$

Sehingga jumlah pelanggan (M) berdasarkan persamaaan (2.1) sebanyak :

$$
\begin{aligned}
M & =\frac{\text { Ax60menit } / \mathrm{hr}}{T} \\
& =266,25 \text { user } / \text { sektor }
\end{aligned}
$$

Channel Sharring dengan 2 sektor sehingga kapasitas pelanggan yang dihasilkan dalam sebuah sel dapat dihitung berdasarkan persamaan (2.3) :

$$
M=\frac{\text { Ax60menit } / h r}{T} \quad \mathrm{x} \quad \text { Jumlah }
$$

sektor

$$
=1597 \text { user }
$$

Tampilan grafik yang dihasilkan :

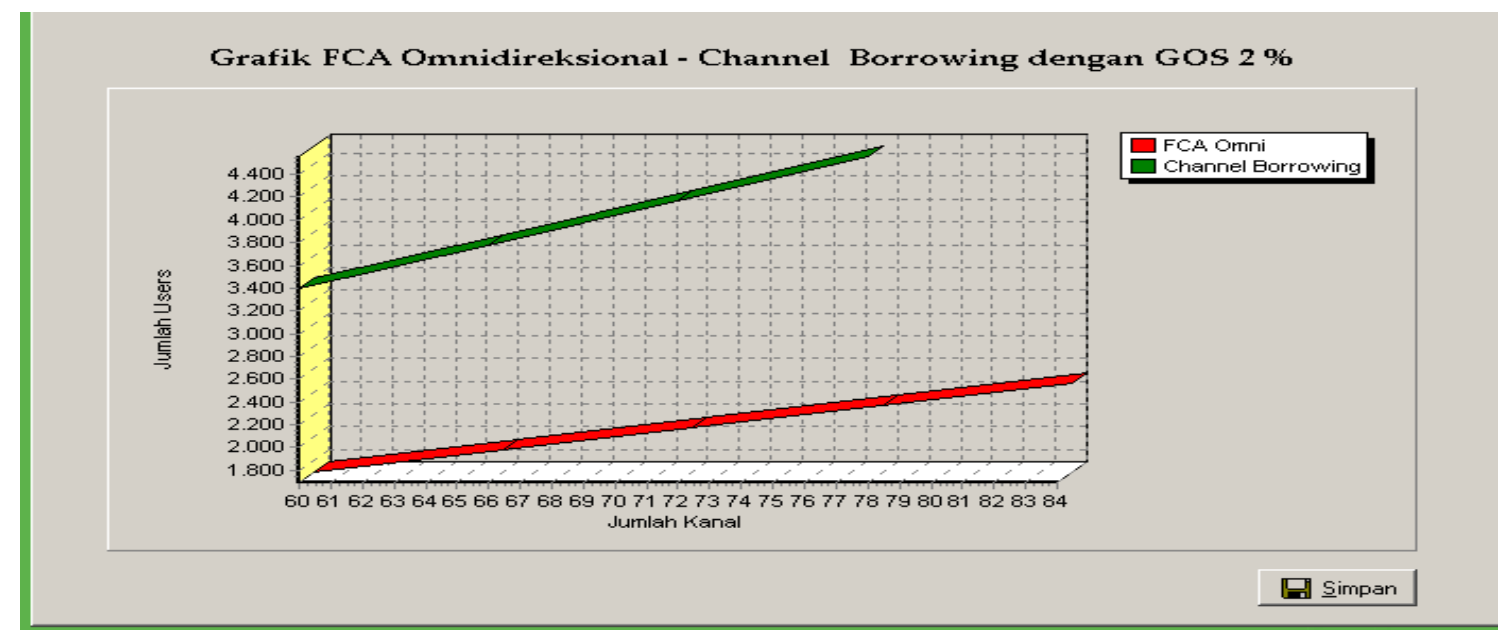

Gambar 4.24 Grafik Perbandingan FCA Direksional dengan Channel Sharing 6 sektor menggunakan probabilitas blocking $5 \%$

Gambar 4.24 menunjukkan grafik perbandingan peningkatan kapasitas antara FCA dan channel sharring 6 sektor dengan kapasitas kanal yang tersedia masingmasing sebanyak 60 kanal dengan waktu pendudukan yang sama mengalami peningkatan dari 1272 pelanggan menjadi
1597 pelanggan yang dapat dilayani dalam satu sel.

3.3 Perbandingan Kapasitas Jumlah Users antara FCA Omnidireksional dengan Channael Borrowing

1. FCA Omnidireksioanal dengan Channel Borrowing dengan probabilitas blocking 2\% 
a. Jumlah kanal per sel yang disediakan $(\mathrm{N})=60 \mathrm{kanal}$

b. Dengan waktu pendudukan $(T)=1,76$ menit

c. Jumlah kanal yang dipinjamkan ke sel tetangga $(\Delta \mathrm{N})=15 \mathrm{kanal}$

d. Dengan waktu pendudukan $(\mathrm{T})=1,76$ menit

\section{a). Perhitungan FCA}

Menghasilkan jumlah pelanggan (M) berdasarkan persamaan (2.1) sebanyak :

$$
\begin{array}{r}
M=\frac{\text { Ax60menit } / \mathrm{hr}}{T} \\
=1690 \text { user }
\end{array}
$$

\section{b). Perhitungan Channel}

\section{Borrowing}

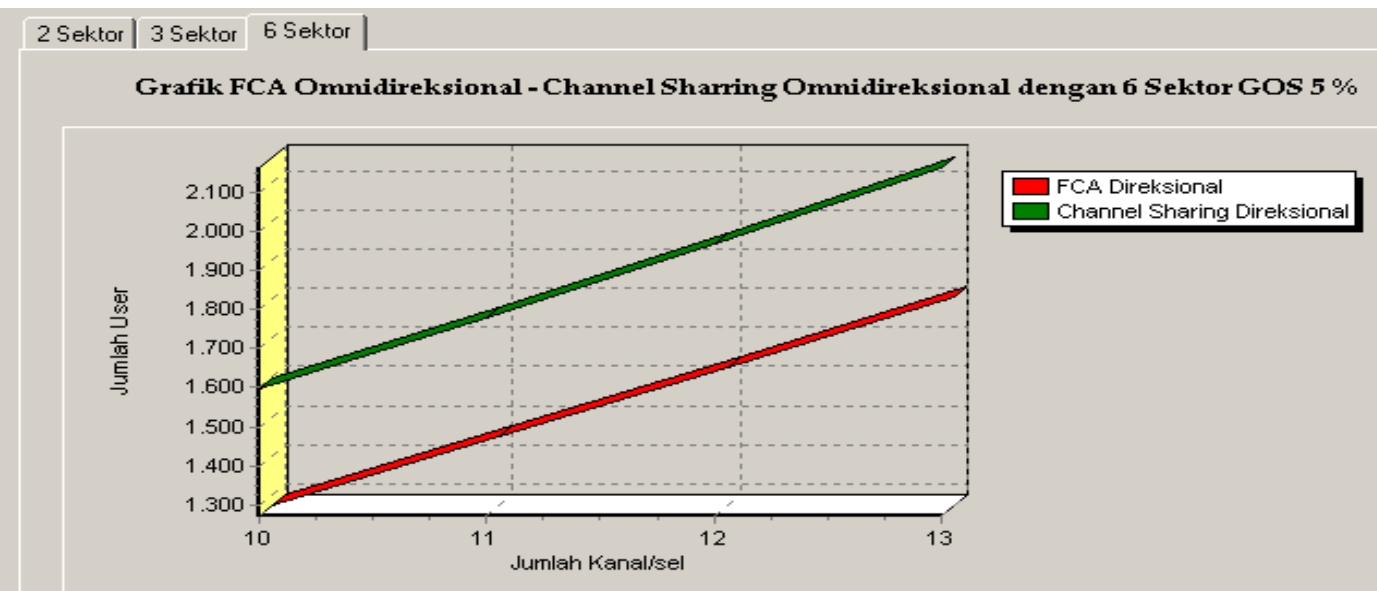

I Simpan

Gambar 4.26 Grafik Perbandingan FCA Omnidireksional dengan Channel Borrowing menggunakan probabilitas blocking $2 \%$

Hasil perhitungan antara FCA omnidireksional dengan skema channel borrowing menghasilkan gambar 4.27,

yang menunjukan adanya peningkatan dengan kapasitas awal
A adalah besar trafik yang dihasilkan berdasarkan persamaan (2.5): $A^{\prime}=A\left(N_{1}+\Delta N ; B\right)+A\left(N_{1}-\Delta N ; B\right)$ (dalam dua)

$=99,5$ Erlang

Sehingga menghasilkan jumlah pelanggan (M) sebanyak :

$$
\begin{aligned}
M & =\frac{\text { Ax60menit } / \mathrm{hr}}{T} \\
& =3392 \text { user } / 2 \mathrm{sel}
\end{aligned}
$$




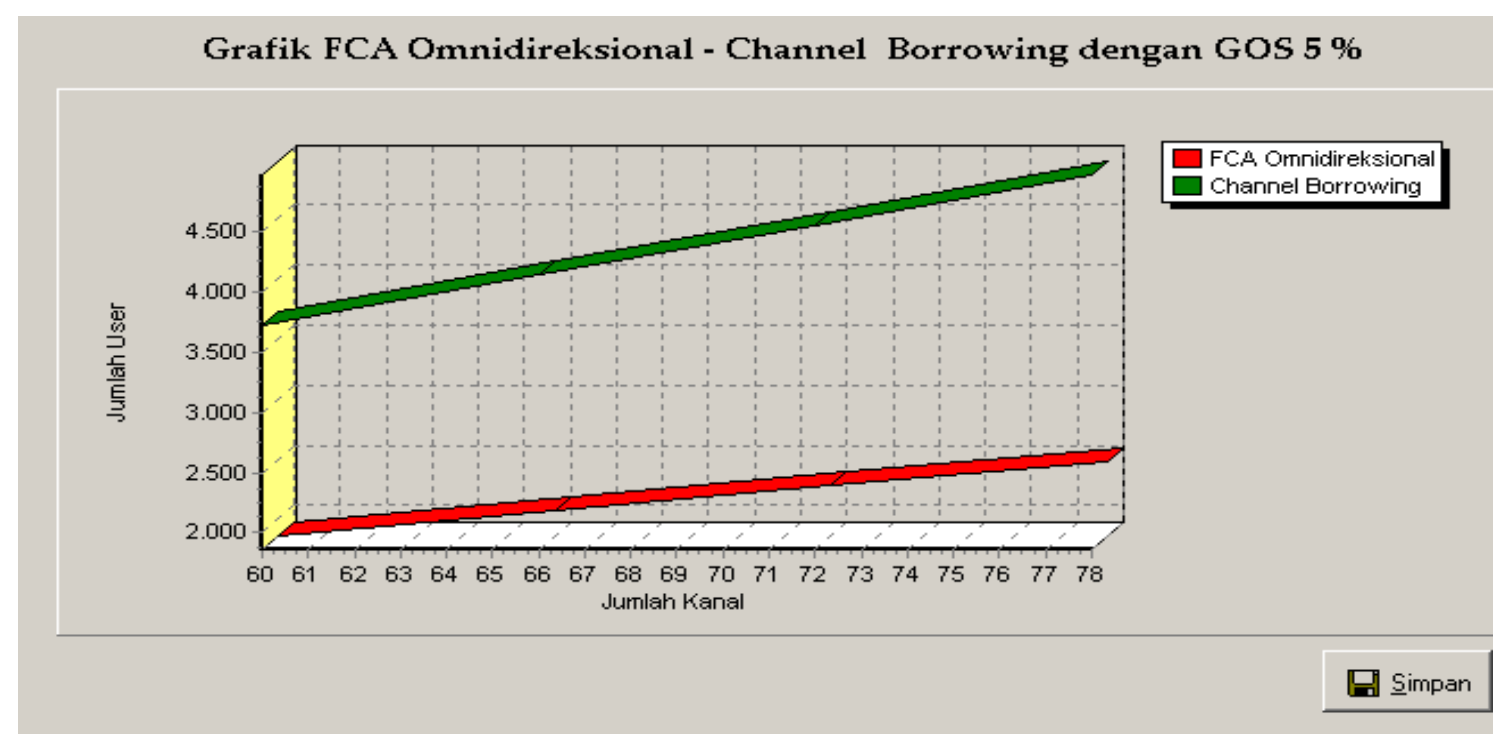

Gambar 4.28 Grafik Perbandingan FCA Omnidireksional dengan Channel Borrowing menggunakan probabilitas blocking $5 \%$

2. FCA Omnidireksional dengan Channael Borrowing dengan probabilitas blocking 5\%

a. Jumlah kanal per sel yang disediakan $(\mathrm{N})$ $=60 \mathrm{kanal}$

b. Jumlah kanal yang dipinjamkan ke sel tetangga $(\Delta \mathrm{N})=15 \mathrm{kanal}$

c. Dengan waktu pendudukan $(T)=1,76$ menit

\section{a). Perhitungan FCA}

Menghasilkan jumlah pelanggan berdasarkan persamaan (2.1) sebanyak :

$$
\begin{gathered}
M=\frac{\text { Ax60menit } / h r}{T} \\
=1861 \quad \text { user }
\end{gathered}
$$

\section{2). Perhitungan Channel Borrowing}

A adalah besar trafik yang dihasilkan berdasarkan persamaan (2.5):

(dalam dua sel)

$$
A^{\prime}=A\left(N_{1}+\Delta N ; B\right)+A\left(N_{1}-\Delta N ; B\right)
$$

$$
=109,3 \text { Erlang }
$$

Sehingga menghasilkan jumlah pelanggan (M) berdasarkan persamaaan (2.1) sebanyak :

$$
\begin{aligned}
M & =\frac{\text { Ax60menit } / \mathrm{hr}}{T} \\
& =3726 \mathrm{user} / 2 \mathrm{sel}
\end{aligned}
$$

Grafik yang dihasilkan berdasarkan hasil perhitungan yaitu :
Pada gambar 4.27 dan gambar 4.28 menunjukkan perbandingan peningkatan kapasitas antara FCA dengan sistem channel borrowing pada sel yang bersebelahan, dimana sistem ini menyediakan sejumlah kanal yang dipinjamkan dari salah satu sel ke sel tetangga. Perbedaan gambar 4.26 dan gambar 4.27 hanya terletak pada penggunaan probabilitas blocking. Dari hasil grafik yang dihasilkan dapat terlihat bahwa semakin banyak jumlah kanal yang tersedia maka semakin banyak jumlah pelanggan yang terdapat dalam sebuah sel.

\subsection{Peningkatan kapasitas sel dengan teknik cell spltting}

\section{1). Perhitungan Radius sel}

Perhitungan radius sel ini diperlukan untuk menentukan seberapa luas besar sel heksagonal yang dapat dibentuk, dengan luas sel heksagonal yang dihasilkan maka dapat diperoleh banyaknya sel yang tersedia dalam suatu luas wilayah tertentu. Perhitungan radius sel merupakan salah satu tahapan dalam sistem perencanaan sel dan sistem area cakupan, sehingga dalam tahapan ini perlu diinputkan parameter data sit eyang dibutuhkan.

Data yang akan diinputkan ke dalam perhitungan radius sel tergantung dari pilihan pada menu utama dimana disediakan 2 menu pilihan propagation pathloss yaitu : Model 
Hata dan Cost 231. Perhitungan dengan model propagasi pathloss dapat dipilih sesuai dengan kriteria nilai parameter yang diasumsikan. Pada perhitungan radius sel disini diasumsikan menggunakan model Hata dengan nilai parameter yang dimasukkan berupa (Sumber : Yuli Afni. Perancangan Perangkat Lunak Estimasi Traffic Voice dan Data pada sistem CDMA20001x. Hal 59) :

a. Frekuensi (fc) : $833,49 \mathrm{MHz}$

b. Redaman lintasan $\left(\mathrm{L}_{50}\right)$ : $115,496 \mathrm{~dB}$

c. Tinggi antena pemancar $\left(\mathrm{h}_{\mathrm{te}}\right): 30$ meter

d. Tinggi antena penerima $\left(\mathrm{h}_{\mathrm{re}}\right): 1,5$ meter

Dengan nilai parameter dihasilkan keluaran berupa :

a. Faktor koreksi $\mathrm{a}\left(\mathrm{h}_{\mathrm{re}}\right)$

b. Radius sel untuk daerah urban

c. Radius sel untuk daerah suburban

Perhitungan yang dihasilkan :

a. Faktor koreksi

Berdasarkan nilai parameter sebagai inputan dan diasumsikan daerah kota besar dengan frekuensi lebih dari $300 \mathrm{Mhz}$ sehingga perhitungan menggunakan persamaan (2.8) :

$$
=-9,19 \times 10^{-4}
$$

b. Radius sel daerah urban :

$$
=0,518 \mathrm{Km}
$$

b. Radius sel daerah suburban :

$$
=0,9147 \quad \mathrm{Km}
$$

Data tersebut diatas dapat diubah sesuai dengan kebutuhan, setelah selesai memasukkan semua inputan kemudian tekan tombol "Hitung" maka secara otomatis nilai dari faktor koreksi $\mathrm{a}\left(\mathrm{h}_{\mathrm{re}}\right)$ yang berdasarkan kriteria wilayah yang telah ditentukan, radius urban sebesar $0,518 \mathrm{~km}$, radius suburban sebesar $0,979 \mathrm{~km}$ dan radius open area sebesar 2,358 $\mathrm{km}$ dapat diketahui. Perhitungan radius sel ini dimaksudkan untuk mendukung perhitungan pada teknik peningkatan kapasitas dengan cara cell splitting untuk tahap perhitungan selanjutnya pada form perhitungan kapasitas kanal dengan menggunakan teknik cell splitting.

\section{2). Perhitungan Teknik Cell Splitting}

Setelah perhitungan radius sel diperoleh dengan cara perhitungan menggunakan model Hata. Pada teknik cell splitting menggunakan asumsi a. Kanal yang tersedia : $30 \mathrm{kanal} / \mathrm{sel}$

a. Luas wilayah $: 16 \mathrm{~km}^{2}$

b. $\quad$ Radius sel $\quad: 0,518 \mathrm{~km}$

Sehingga dapat diperoleh jumlah kanal yang tersedia pada saat sel sebelum mengalami cell splitting dengan kapasitas kanal setelah mengalami cell splitting :

a. Sebelum mengalami cell splitting :

- $\quad$ Luas sel heksagonal :

$$
\begin{aligned}
& \mathrm{L}=2,6 \mathrm{R}^{2} \\
& =2,6 \times 0,518^{2} \\
& =0,697 \mathrm{~km}^{2}
\end{aligned}
$$

Jumlah sel :

$$
L_{\text {sel }}=\frac{\text { LuasDaerah }}{\sum s e l}
$$

sehingga :

$$
\sum_{\text {sel }}=\frac{\text { LuasDaerah }}{L_{\text {sel }}}
$$

$\cong 22 \mathrm{sel}$

\section{- Jumlah kanal}

Jumlah kanal yang tersedia untuk satu wilayah sebanyak $22 \times 30 \mathrm{kanal}=660$ kanal, dimana untuk masing-masing sel terdiri dari $30 \mathrm{kanal} / \mathrm{sel}$.

b. Setelah mengalami cell splitting:

- $\quad$ Luas sel heksagonal :

$$
\begin{aligned}
& \mathrm{L}=2,6 \mathrm{R}^{2} \\
& =2,6 \times 0,259^{2} \\
& =0,174 \mathrm{~km}^{2}
\end{aligned}
$$

$$
\text { - Jumlah sel : }
$$

$$
L_{\text {sel }}=\frac{\text { LuasDaerah }}{\sum \text { sel }}
$$

sehingga

$$
\begin{aligned}
& \sum_{\text {sel }}=\frac{\text { LuasDaerah }}{L_{\text {sel }}} \\
= & \frac{0,697}{0,174} \\
= & 4 \mathrm{sel}
\end{aligned}
$$

\section{- Jumlah kanal}

Jumlah kanal diperoleh dengan mengalikan $\mathrm{kanal} / \mathrm{sel}$ yang disediakan dengan 
banyaknya sel yang dihasilkan sebesar : $4 \times 30=120 \mathrm{kanal} / \mathrm{sel}$

Pada dasarnya teknik cell splitting merupakan sistem teknik dengan cara membagi-bagi sebuah sel menjadi selsel yang memiliki wilayah cakupan yang lebih kecil. Pada asumsi diatas terdapat luas wilayah tertentu yaitu sebesar 16 $\mathrm{km}^{2}$, dengan radius sel sebesar 0,518 $\mathrm{km}$ dan kapasitas kanal yang tersedia sebanyak $30 \mathrm{kanal} / \mathrm{sel}$ sehingga dengan menggunakan persamaan yang ada dapat diperoleh kapasitas kanal yang tersedia. Dalam perhitungan yang telah dilakukan baik secara manual ataupun dengan alat bantu diperoleh hasil yang tidak jauh berbeda, dimana terlihat bahwa kapasitas yang dihasilkan sebelum mengalami cell splitting dan setelah mengalami cell splitting terjadi peningkatan kapasitas dari 660 kanal dalam satu wilayah menjadi 2640 kanal dalam satu wilayah yang sama, sedangkan kapasitas per sel yang diperoleh sebesar $30 \mathrm{kanal} / \mathrm{sel}$ menjadi $120 \mathrm{kanal} / \mathrm{sel}$, hal ini menunjukkan adanya peningkatan kapasitas sebanyak 4 kali lipat kapasitas sel yang lama sesuai denga teori yang dikemukakan yaitu dengan cara memperkecil cakupan radius sel menjadi $\mathrm{R} / 2$, agar membentuk sel-sel mikro sehingga dapat meningkatkan kapasitas sel.

\section{Penutup}

\subsection{Kesimpulan}

1. Peningkatan kapasitas sel dapat dilakukan dengan menggunakan teknik Channel Sharing, Channel Borrowing baik menggunakan antena omnidireksional maupun dengan antena direksional dan teknik Cell Splitting, dimana dengan menggunakan teknik tersebut akan menaikkan kapasitas sel jika dibandingkan dengan kapasitas sel lama (Fixed Channel Allocation).

2. Pada teknik Channel Sharing dan Channel Borrowing semakin banyak jumlah kanal yang tersedia maka semakin banyak pula kapasitas pelanggan yang dapat dilayani dalam sebuah sel.
3. Tingkat probabilitas yang digunakan dapat menaikkan jumlah pelanggan yang dapat tercover.

4. Pada teknik cell splitting terjadi peningkatan kapasitas kanal hingga mencapai empat kali lipat dari kapasitas kanal yang tersedia sebelumnya.

\subsection{Saran}

1. Pada teknik cell splitting dalam penganalisaan dapat mengunakan data real suatu daerah.

2. Dapat lebih mendalam dalam proses analisa pada masing-masing teknik peningkatan kapasitas sel.

\section{Daftar Pustaka}

[1] Afni, Yuli, "Perancangan Perangkat Lunak Estimasi Trafik Voice dan Data Pada Sistem CDMA 1x", STTelkom, Bandung, 2004.

[2] Hikmaturokhman, A.," Modul Kuliah Jarlokar " Akatel Sandhy Putra Purwokerto, Purwokerto.

[3] Lee, William C.Y., " Mobile Communications Desigh Fundamental ", Second Edition.

[4] Silalahi, Nurain. "Komunikasi Mobil Public dan Sistem Komunikasi Mobil Personal PCS", Jakarta, PT Elex Komputindo, 2003.

[5] Sunomo., " Pengantar Sistem Komunikasi Nirkabel ", Jakarta, PT Grasindo, 2004.

[6] Technology GSM Introduction, Siemens. 2002

[7] UPLATDA, " Sistem Komunikasi Bergerak ”, PT Telkomsel (GSM Spesialist), Ujung Pandang.

http://www.stttelkom.ac.id/staf/UKU/Materi \%20Kuliah\%20SISKOMBER/TE.4103SISKOMBER\%20S1/Materi\%20Setelah \%20UTS-SISKOMBER\%20S1/ PENDAHULUAN\%20TEORI\%20TRA FIK.doc (27 Juni 2006) 